\title{
УДК 347.1
}

DOI https://doi.org/10.32840/1813-338X-2019-2-4

\section{О. А. Журавель}

аспірант кафредри адміністративного права, процесу та адміністративної діяльності Дніпропетровського державного університету внутрішніх справ

\section{ЗАКОННІСТЬ ТА УМОВИ ПРАВОМІРНОСТІ РЕАЛІЗАЦІЇ ГРОМАДЯНАМИ ПРАВА НА САМОЗАХИСТ}

У cmammi, на основі аналізу чинного законодавства та практики його реалізації, визначаються наявні наукові та нормативні джерела, визначається сутність правомірності реалізації права громадян на самооборону та визначаються умови її законності.Проаналізовано чинне законодавство, що регулює питання самозахисту, а також заходи щодо його застосування.

Ключові слова: самооборона, захист прав і свобод, припинення посягань, фрорми, методи самозахисту, засоби самозахисту, умови самозахисту, межі самозахисту.

Постановка проблеми. Гарантування людині права на самозахист зобов'язує державу здійснити правове регулювання умов, під час яких вона може самостійно захищати свої права і свободи. Такий обов'язок знаходить реалізацію у Конституції України, де, насамперед, зазначено, що держава відповідає перед людиною за свою діяльність, а утвердження і забезпечення прав і свобод людини є головним обов'язком держави (стаття 3). Навіть більше, Конституція України надає особі право будь-якими не забороненими законом засобами захищати свої права і свободи від порушень і протиправних посягань [1].

Проголошення на конституційному рівні широких меж особистої свободи, надання громадянам значних можливостей щодо реалізації своїх прав та інтересів зумовлює необхідність самостійного визначення права на їх розумний захист. Тим більше, що права і свободи в переважній більшості втрачають своє значення, якщо громадянин не в змозі самостійно їх захищати. 3 урахуванням цього в галузевому законодавстві зафріксовано право на здійснення оборонних заходів проти суспільно небезпечного посягання незалежно від наявності можливості звернутися за допомогою до інших осіб чи органів влади. Разом з тим, громадяни рідко готові скористатися правом на самозахист, причинами чому називають: страх настання небажаних правових наслідків (48\%); незнання конкретних правил поведінки (19\%); незнання конкретних правових приписів $(17 \%)$; наявність відомостей лише про негативний досвід настання наслідків практичної реалізації права на самозахист (11\%), а також недооцінка власних сил і можливостей (5\%) [2]. Таким чином, громадяни побоюються не стільки зіткнення з правопорушником, скільки подальших наслідків. У подібних випадках зазвичай заведено звинувачувати закон, однак справа полягає не стільки в самому законі, скільки в практиці його застосування. I тут надзвичайно важливим питанням $\epsilon$ визначення умов правомірності самозахисту прав громадян та меж дотримання законності застосування відповідних засобів.

Аналіз публікацій, в яких започатковано розв'язання даної проблеми. На жаль, доводиться констатувати, що правовий захист людини викликає небезпідставне занепокоєння не лише у керівництва держави, а й у широкого наукового та громадського загалу. Названій проблемі присвячено роботи В.Б. Авер'янова, С.М. Алфьорова, І.В. Арістової, О.М. Бандурки, А.І. Берлача, Ю.П. Битяка, В.Т. Білоуса, І.Л. Бородіна, М.Г. Вербенського, І.П. Голосніченка, К.О. Гориславського, В.Л. Грохольського, С.М. Гусарова, П.В. Діхтієвського, Є.В. Додіна, Р.А. Калюжного, С.В. Ківалова, В.В. Коваленка, А.Т. Комзюка, В.К. Колпакова, О.Г. Комісарова, О.В. Копана, М.В. Корнієнка, В.І. Курила, Є.В. Курінного, М.Н. Курка, К.Б. Левченко, Д.М. Лук'янця, В.І. Олефріра, О.С. Остапенка, В.П. Пєткова, С.В. Пєткова, А.М. Подоляки, Т.О. Проценка, О.П. Рябченко, С.Г. Стеценка, М.П. Стрельбицького, В.К. Шкарупи та багатьох інших вчених. Однак, попри те, що галузеве законодавство проголошує правові можливо- 
сті людини на самозахист, єдиного механізму ефрективного захисту громадянами своїх конституційних прав дотепер не вироблено, як і не має чіткого усвідомлення про умови правомірності самозахисту та відповідні його межі.

Мета статті полягає у з'ясуванні сутності законності використання засобів самозахисту та визначенні умов правомірності їх застосування.

Виклад основного матеріалу. Попри конституційне закріплення права кожної особи будь-якими не забороненими законом засобами захищати свої права і свободи від порушень і протиправних посягань, держава не в змозі передбачити та запобігти кожній окремій неправомірній поведінці. Така ситуація зумовлює необхідність забезпечення незалежного від різноманітних зовнішніх чинників захисту прав й інтересів та реалізації відповідного права на захист особисто. Власне через самозахист можливе як недопущення виникнення певного конфрлікту чи його подальшого розвитку, так і врегулювання вже наявного. Саме самозахист $€$ первинним видом незалежного, позасудового захисту прав та інтересів людини.

Самостійному захисту прав і свобод, при якому сама особистість визначає спосіб і порядок забезпечення своїх прав, у вітчизняному законодавстві відводиться більш ніж другорядна роль, у зв'язку з цим і в юридичній літературі більшою мірою досліджуються судові та адміністративні форми захисту. Однак, наявні проблеми у функціонуванні механізму захисту прав особи, нездатності держави в певних випадках захистити її інтереси, вимагає розширення правових засобів щодо реалізації конституційного права людини на захист своїх прав і свобод.

На жаль, сьогодні, як ніколи раніше, тема законності використання засобів самозахисту $€$ актуальною і, так або інакше, стосується кожного. 3 причини відсутності необхідних знань часто засоби самозахисту застосовуються 3 порушеннями норм законодавства, в тому числі мають місце випадки перевищення меж необхідної оборони. Водночас саме додержання необхідних меж самозахисту обґрунтовано слід вважати продовженням принципу законності, адже перевищенням меж необхідної оборони визнається умисне заподіяння тому, хто посягає, тяжкої шкоди, яка явно не відповідає небезпечності посягання або обстановці захисту.

Перевищення меж самозахисту згідно з чинним законодавством тягне кримінальну відпові- дальність лише у випадках, спеціально передбачених Кримінальним кодексом України [3]. Водночас не буде вважатися перевищенням меж необхідної оборони та не матиме наслідком кримінальну відповідальність застосування зброї або будь-яких інших засобів чи предметів для захисту від нападу озброєної особи або нападу групи осіб, а також для відвернення протиправного насильницького вторгнення у житло чи інше приміщення, незалежно від тяжкості шкоди, яку заподіяно тому, хто посягає. Ці умови передбачені ст. 36 Кримінального кодексу України (далі - ККУ), проте більш докладно розвинуті Верховним Судом (далі - ВС) у низці рішень, що складають єдину та послідовну правозастосовну практику. Зокрема, із постанови ВС від 20 листопада 2018 р. по справі № 490/11155/14-к 20 слідує, що до критеріїв визначення правомірності необхідної оборони належать: наявність суспільно небезпечного посягання, його дійсність та об'єктивна реальність, межі захисних дій, які б не перевищували меж необхідності, а шкода особі, яка здійснює посягання, не перевищувала б ту, яка для цього необхідна [4].

Більш розгорнуті критерії наразі визначені у постанові ВС від 19 квітня 2018 р. по справі № 722/1981/16-к, серед яких зокрема:

1) оборона визнається необхідною лише у випадку, якщо дії, що становлять її зміст, вчинено з метою захисту охоронюваних законом: а) прав та інтересів особи, яка захищається; б) прав та інтересів іншої особи (фрізичної чи юридичної); в) суспільних інтересів; г) інтересів держави;

2) оборона може здійснюватись лише від суспільно небезпечного посягання, тобто діяння, ознаки якого передбачені КК;

3) за загальним правилом необхідна оборона має бути своєчасною - право на неї втрачається після того, як посягання було припинено або закінчено, і необхідність застосування засобів захисту відпала;

4) посягання має бути реальним, а не існувати лише в уяві того, хто захищається;

5) шкода при необхідній обороні може бути заподіяна тільки тому, хто посягає;

6) при необхідній обороні допускається заподіяння лише такої шкоди, яка $є$ необхідною і достатньою в даній обстановці для негайного відвернення чи припинення посягання [5].

Однак, зрозуміло, що кожне право має свої межі, адже безмежне лише свавілля, тому і необхідна оборона має власні межі аби вважатися правомірною. 
Ще одним винятком правозастосовної практики є рішення Колегії суддів Другої судової палати Касаційного кримінального суду Верховного суду, яка постановою у справі № 342/538/14-к (провадження № 51-646км18) скасувала вирок чоловікові, якого визнали винним у перевищенні меж самооборони. Тим самим суд підтвердив право на позбавлення життя при захисті від нападу групи осіб, які протиправно вдерлися в житло. Сам закон, зокрема його ст. 36 ч. 5 ККУ про самооборону передбачає застосування зброї для самозахисту. Закон є своєрідним винятком із загального правила про необхідність дотримання меж самозахисту і передбачає, що у ситуаціях із нападом групи осіб, озброєної особи, або протиправного насильницького вторгнення у житло чи інше приміщення особа не має жодних обмежень у самообороні, аж до позбавлення життя посягаючого [6].

Закордонна практика також не дає однозначної відповіді на питання про правомірність самозахисту та його відповідні межі. Наприклад, американський закон не стільки захищає право на самооборону, скільки дає чітку лінію захисту на суді для того, щоб зрозуміти, наскільки було правомірним використання летальної зброї при самообороні. Зокрема суди використовують «тест Норріса», що складається із чотирьох пунктів:

1) той, хто обороняється, повинен чітко усвідомлювати, що він застосовує смертоносне насильство для запобігання серйозних каліцтв чи вбивства себе або інших. Головним $є$ розуміння такої особи, що їі дії можуть призвести до смерті, і вона до цього готова. При самообороні у людини має бути умисел на можливе вбивство: той, хто обороняється, застосовує зброю усвідомлено, усвідомлюючи, що може вбити людину. Якщо ж на суді він скаже, що не планував нікого вбивати, то у нього втрачається право на самозахист: йому просто інкримінують вбивство з необережності. Однак в будь-якому випадку при самообороні людина має право стріляти, тільки коли вона переконана в обґрунтованості та необхідності вбивства;

2) обставини повинні підтверджувати, що ситуація не залишила нічого іншого, крім як зробити обґрунтоване вбивство. Такими обставинами можуть бути: наявність зброї у нападника, чисельна перевага агресорів, силове проникнення в будинок (в деяких штатах в машину або на місце роботи), диспропорція у фізичній силі у нападника і того, хто захищається;
3) той, хто обороняється, не тільки не має права першим застосувати силу, але навіть будь-яким чином спровокувати нападника, інакше він втратить право на самооборону. В цьому випадку подію буде кваліфіковано як сутичку рівноправних учасників або навіть як напад з боку «жертви»;

4) використання сили має бути пропорційним агресії, тобто смертоносне насильство не може бути застосоване для захисту власності, за винятком захисту будинку від підпалу, що прирівнюється до спроби силового проникнення, або для захисту себе від незначного збитку. Лише, якщо всі чотири пункти будуть задоволені, самооборона вважатиметься обґрунтованою [7].

Отже, важливе значення для реалізації самозахисту громадянами своїх прав, є обґрунтування умов правомірності такого захисту. У законодавстві України такі умови не знайшли свого відбиття. Найбільш вдалим, як нам видається, $є$ перелік умов правомірності самозахисту, запропонований М. Брагінським, на його думку, для правомірного самозахисту досить дотримання таких умов: особа, яка самостійно захищає своє право, є безперечним його власником; обраний особою спосіб самозахисту повинен бути співмірним з порушенням; спосіб самозахисту не може виходити за межі дій, необхідних для його застосування [8, с. 70].

Правомірність самозахисту прямо пов'язано із небезпекою як для окремої людини, так і для інтересів третіх осіб, суспільства і держави. Саме небезпека викликає потребу в реалізації належного людині права на захист власних інтересів всіма не забороненими законом способами, в тому числі й правомірним застосуванням насильства, що можливо через три важливі умови: джерело небезпеки (будь-який зовнішній фактор (подія або стан), що створює загрозу заподіяння шкоди законним інтересам особистості, суспільства або держави), наявність небезпеки (самозахист можливий, якщо посягання вже почалося, а держава в особі уповноважених органів ще адекватно не прореагувало на порушення або загрозу порушення прав і свобод особи) та дійсність небезпеки (така небезпека повинна існувати насправді, а не в уяві людини).

Умови правомірності самозахисту тісно пов'язані з межами використання охоронних засобів при наявності протиправних посягань з боку особи, якій вони завдають шкоду. 3 цього приводу Ляшевська Л.І. цілком слушно наголошує, що такі межі 
мають бути загальними та визначатися з урахуванням цінності охоронюваних об'єктів і з урахуванням того, що спричинення правопорушнику смерті може бути виправдане лише його посяганням на життя і здоров'я особи. Якщо ж загроза життю чи здоров'ю особи, що викликана засобами охорони, не $€$ реальною, однак такі засоби, проте, завдають шкоду особі (наприклад, якщо порушники проникають на територію, де міститься огорожа, з метою переховатися, однак зазнають шкоди життю чи здоров'ю), то в такому разі питання меж самозахисту визначається обставинами заподіяння шкоди аналогічно удаваній обороні. Однак при удаваній обороні наявна суб'єктивна сторона - відношення особи, яка самозахищається, до відповідного діяння іншої особи, а при використанні способів охорони таке відношення відсутнє [9, с. 109].

Відтак, межі самозахисту тісно пов'язані з його умовами та полягають у тому, що:

1) захисні дії не повинні перебувати в явній невідповідності з характером і ступенем небезпеки, що загрожує людині або суспільству. Іншими словами, об'єкт захисних дій не повинен бути більш значущим, ніж об'єкт небезпеки. Наприклад, при виникненні небезпеки для життя того, хто захищається він має право завдати шкоди будь-яким охоронюваним законом інтересам, аж до заподіяння смерті іншій особі;

2) порушуваним інтересам не повинно бути завдано рівної або більш значної шкоди, ніж відверненої. В такому випадку заподіяння смерті буде визнаватися правомірним тільки в ситуації порятунку життя декількох осіб.

Не слід механічно підходити до співвідношення об'єктів небезпеки та захисту: важливо оцінювати не тільки якісну, але і кількісну характеристику порушуваних прав, обставини заподіяння шкоди (умови місця, часу та інше), а так само емоційний стан особи, змушеної приймати рішення в екстремальних умовах самозахисту.

Заподіяння смерті людині в стані крайньої портеби можливе тільки в виняткових випадках (при врятуванні життя кількох осіб, забезпеченні важливих державних і громадських інтересів, охорони миру і безпеки людства).

Для визнання цих дій правомірними важливо встановити такі ознаки об'єктивної сторони: 1) наслідків, що дозволяють встановити відповідність заподіяної шкоди, адже остання, якщо заподіюється інтересам третіх осіб при усуненні небезпеки, має бути менш значною, ніж шкода відвернена. Однак це не означає, що «шкода має бути найменшою 3 можливих» [10, с. 87];
3) часу здійснення захисних дій (вимога своєчасності захисту). Реалізація права на самозахист обмежена часовими рамками: з моменту виникнення небезпеки заподіяння шкоди громадянину, правам інших осіб, охоронюваним законом інтересам суспільства або держави до ії усунення. Якщо ж діяння відбувається поза цими межами - воно визнається протиправним і підлягає оцінці на загальних підставах.

Висновок. Отже, основу інституту самозахисту складає конституційна ідея забезпечення балансу різних інтересів учасників суспільних відносин і неприпустимості обмеження прав і свобод одного суб'єкта коштом іншого. Саме на державу покладається обов'язок правового регулювання меж самозахисту відповідно до конституційних основ цього інституту.

Питання самозахисту прав і свобод громадян, а також його меж в законодавстві врегульовано недостатньо, що вказує на необхідність надання громадянам ширших прав в цій сфрері. Це дозволить досить виважено підходити до захисту прав і свобод людини, сприяти зменшенню криміналізації суспільства і підвищенню рівня правової культури. Поки ж громадяни надають перевагу таким способам захисту своїх прав, які іноді виходять за межі закону, елементарно не знаючи як діяти в певній ситуації та якими правами вони володіють, адже закон, на жаль, не дає однозначної відповіді на це питання. Дотепер немає спеціального нормативного акта, присвяченого визначенню меж самозахисту.

Слід визнати, що самостійний захист прав у формах, порядок реалізації яких не встановлено нормативно-правовими актами, представляє для особи небезпеку притягнення до відповідальності за самоуправство, передбачене нормами кримінального та адміністративного права. У зв'язку з цим сфера застосування права на самозахист повинна бути обмежена тільки заходами, межі та порядок реалізації яких встановлено виключно чинним законодавством. Однак, ні в теорії, ні в практиці правозастосування поки не склалося одностайної думки про умови правомірності самозахисту, тому в кожному конкретному випадку ця норма тлумачиться за внутрішнім переконанням особи, яка її застосовує. Оскільки захист самостійними діями може заподіяти шкоди та призвести до негативних наслідків, існує нагальна потреба чіткого визначення умов та меж самозахисту, тому що будь-які сумніви в їх правомірності $\epsilon$ неприпустимими та порушуватимуть встановлений державою режим законності. 


\section{Список використаної літератури:}

1. Конституція України : Закон України. Відомості Верховної Ради України. 1996. № 30. Ст. 141.

2. Дядюн К.В. Право на необходимую оборону: проблемы реализации. Universum: Экономика и юриспруденция : электрон. научн. журн. 2014. № 5 (6). URL: http://7universum.com/ru/ economy/archive/item/1281

3. Кримінальний кодекс України : Закон України від 5 квітня 2001 р., № 2341-ІІІ. Офріиійний вісник України. 2001. № 21. Ст. 920.

4. Єдиний державний реєстр судових рішень URL: http://reyestr.court.gov.ua/Review/78111068

5. Право на безмежну самооборону або обґрунтоване вбивство URL: https://protocol.ua/ru/ pravo_na_bezmegnu_samooboronu_abo_ob_ runtovane_vbivstvo/
6. Верховний Суд визнав убивство під час вторгнення у житло легальним заходом самооборони URL: https://zaxid.net/verhovniy_sud_ukrayini_ viznav_ubivstvo_pid_chas_vtorgnennya_u_zhitlo_ legalnim_zahodom_samooboroni_n1458243

7. Как защищают жизнь и имущество в Америке и Европе URL: https://www.ridus.ru/news/231765

8. Крупка Ю.М. Самозахист як спосіб захисту прав суб'єктів господарювання. Вісник Університету «Україна». 2010. № 1. С. 68-71.

9. Ляшевська Л.І. До питання співвідношення самоохорони і самозахисту права власності в Україні. Проблеми законності. 2017. Вип. 139. C. 105-112.

10.Кириченко В.Ф. Значение ошибки по советскому уголовному праву / Отв. ред.: Маньковский Б.С. Москва : Изд-во АН СССР, 1952. 96 с.

\section{Журавель А. О. Юридические условия юридической реализации права на самозащиту \\ В статье на основе анализа действующего законодательства и практики его приме-} нения, имеющихся научных и нормативных источников, определена сущность законности реализации права граждан на самооборону и определены условия его законности. Анализируется действующее законодательство, регулирующее вопросы самообороны, а также меры по его применению.

Ключевые слова: самооборона, защита прав и свобод, прекращение посягательств, формы, методы самообороны, средства самообороны, условия самообороны, пределы самообороны.

\footnotetext{
Zhuravel A. O. Legality and conditions of legality of civic realization of the right to selfdefense

In the article, based on the analysis of current legislation and practice of its implementation, available scientific and normative sources, the essence of the lawfulness of the realization of the right of citizens to self-defense is determined and the conditions of its legality are determined. The current legislation regulating self-defense issues is analyzed, as well as measures for its application.

Key words: self-defense, protection of rights and freedoms, termination of encroachment, forms, methods of self-defense, means of self-defense, conditions of self-defense, and limits of self-defense.
} 